\title{
SOME ASPECTS OF SECURING A PERSONAL NON-PROPRIETARY RIGHT TO HEALTH
}

\section{Manzhosova O. V.}

\section{INTRODUCTION}

The ideology of "human-centrism" enshrined in the current Constitution of Ukraine is a legal phenomenon of the European level, but it does not require declarative but real implementation of modern legal relations and norms of Ukrainian legislation.

Against this background, there is a need to rethink individual civil law institutions, in particular one of the types of personal non-property rights of an individual envisaged by the rules of the current Civil Code of Ukraine right to health and medical care ${ }^{1}$.

These rights belong to the group of personal non-property rights that ensure the natural existence of human beings, are inalienable, necessary and should be protected, because human health is the overriding social value of the modern state and the basis for future generations.

These rights individualize the persone and promote personal freedom, that is, the ability to freely choose different behaviors within social relationships. That is one of the conditions of active human life.

At the general legal level the rights of individuals in the sphere of health care are a set of fundamental, inalienable, natural rights that are individual in nature and enable a person to use the methods prescribed by law to ensure the proper functioning of his body as a whole.

In civil law, the idea of personal non-property rights of individuals in the sphere of health are personal civil rights.

These rights of origin are natural. Their contents contain the possibility of using certain means for the preservation, development, strengthening and restoration in case of violation of the human body condition, provided that such use does not violate the rights of others ${ }^{2}$.

According to current researchers, the right to health care and medical care fall into the category of personal non-property rights of individuals arising in the field of medical relations, and can be defined as the rights of patients.

\footnotetext{
${ }^{1}$ Цивільний кодекс України від 16. 01. 2003p. № 435-IV. Відомості Верховної Ради України. 2003. № № 40-44. Ст. 356.

${ }^{2}$ Коротка Н.О. Особисті немайнові права фізичних осіб в сфері охорони здоров'я : автореф. дис. ... канд. юрид. наук : 12.00.03. Київ, 2015. 20 с.
} 
Their content is, among other things, rights related to the provision of medical care (the right to provide medical care in conditions that meet the hygiene requirements; the right to respect and humane treatment by medical and care staff; the right to choose a doctor, treatment method and medical institution) $)^{3}$.

The special, "exclusive" meaning of these rights is absolute, and just as unconditional is the mechanism of their realization in Ukraine.

Art. 49 of the Constitution of Ukraine establishes a mechanism for implementing the legal right of a person to health care and adequate medical care ${ }^{4}$. In addition, the decision of the Constitutional Court of Ukraine of May 29, 2002 made it compulsory to provide free medical assistance to all citizens in full, and not only "necessary medical assistance and social services",

The specificity of securing and exercising certain rights lies in the current and legally enforceable health care system based on budgetary financing.

Negative manifestations of this situation are complaints about the lack of sufficient budget financing of the medicine industry. This is the declarative nature of the principle of free medical care, because its provided by state and municipal medical institutions at the actual "payment" of their services, low salaries of medical workers, etc.

\section{Reforming medicine as an effective way of securing a non-material right to health care}

Today, Ukraine is actively reforming the medical sector. One of the areas of reform is the ability of citizens to freely choose a primary care physician (family doctors, pediatricians) and sign direct agreements with them with a clearly spelled-out amount of services guaranteed and paid for by the state.

The Law of Ukraine "On State Financial Guarantees of Medical Services to the Population" defines issues of contractual relations in a somewhat different way ${ }^{6}$. Article 8 of the Law establishes the concept of "public health

${ }^{3}$ Стефанчук Р. О. Особисті немайнові права фізичних осіб у цивільному праві :автореф. дис. ... докт. юрид. наук: 12.00.03. Київ, 2007. 40 с.

${ }^{4}$ Конституція України : офіц. текст. Київ : КМ, 2013. 96 с.

${ }^{5}$ Рішення Конституційного Суду України у справі за конституційним поданням 53 народних депутатів України щодо офіційного тлумачення положення частини третьої статті 49 Конституції України "у державних і комунальних закладах охорони здоров'я медична допомога надається безоплатно" (справа про безоплатну медичну допомогу) від 29.05.2002. URL: https://zakon.rada.gov.ua/laws/show/v010p710-02 (дата звернення 11.01 .2020

${ }^{6}$ Про державні фінансові гарантії медичного обслуговування населення: Закон України від 19.10.2017p. № 2168-VIII. Відомості Верховної Ради. 2018. № 5. Ст. 31. 
contract". This is an agreement between medical institutions of different ownership and physicians registered as natural persons-entrepreneurs and relevant state authorities in the sphere of health care. The contract on public health services is concluded in writing (including electronic) between the National Health Service of Ukraine and health care institutions of all forms of ownership and individuals-entrepreneurs who are licensed to conduct business activities in medical practice.

The contract of public health services regulates and determines the terms and scope of medical services and medicines. The contract establishes requirements for the quality of services, the procedure for payment of the coverage rate for medical services and medicines provided, the rights and obligations of the parties, as well as the responsibility for non-compliance or improper fulfillment of the terms of such contract. The public health contract is a contract for the benefit of third parties - patients in the provision of medical services and medicines to healthcare providers.

The essential conditions of the contract on medical care of the population due to the program of medical guarantees are:

- the list and volume of provision of medical services and medicines to patients under the medical guarantee program;

- conditions, procedure and terms of payment of the tariff;

- the actual address of the medical service;

- rights and duties;

- term of the contract; reporting of health care providers; responsibilities of the parties ${ }^{7}$.

With regard to the issue of legal relationship between a particular health care provider and a patient, the aforementioned law operates with the concept of "declaration of choice of primary care physician", which must be submitted by the patient at the first request for medical services.

Considering the envisaged possibility of entering into a contract for the provision of medical services between the doctor (health care provider) and the patient (customer, consumer of the service), the following should be noted. The defined contract is a civil law category and belongs to a group of service contracts.

The Civil Code of Ukraine stipulates that under a service contract, one party (the executor) undertakes to provide a service that is consumed in the course of committing a certain act or carrying out a certain activity, and the client undertakes to pay the contractor specified service, unless otherwise

7 Про державні фінансові гарантії медичного обслуговування населення: Закон України від 19.10.2017p. № 2168-VIII. Відомості Верховної Ради. 2018. № 5. Ст. 31. 
stipulated in the contract (Article 901), but there is a possibility of providing services free of charge . $^{8}$

Under the agreement of medical services, health care institutions are contractors. There are legal entities of any form of ownership and legal form or their separate divisions. Their main task is to provide public health services on the basis of an appropriate license and professional activity of medical (pharmaceutical) workers ${ }^{9}$.These are also individuals who could carry out private medical practice.

It should be noted that the network of state and communal healthcare institutions is formed taking into account the needs of the population in health care, the need to ensure the proper quality of such services, timeliness, accessibility for citizens, efficient use of material, labor and financial resources.

The establishment and operation of private health facilities is supported by the state. The need to create a private healthcare facility is determined not by the state but by the owner based on market research of the health care services market and at his own risk ${ }^{10}$.

The doctor is invited to choose any legal form, namely to acquire the legal status of an individual entrepreneur or to work in a polyclinic, an outpatient clinic or a Center for primary health care. And if the ability of an individual entrepreneur to be a party to a contract for the provision of service issues does not arise, then the possibility of a doctor, who is a hired employee in the relevant legal entity, raises a number of questions regarding the legal status of the parties to the contract and the content of the contract itself.

Despite the fact that in accordance with the provisions of Art. 902 of the Civil Code of Ukraine the contractor must provide the service personally, the contracting party is a health care institution, not a specific health care provider, but the latter may, on the initiative of the Ministry of Health of Ukraine, be indicated in the contract as a direct provider of specific medical services. However, according to the provisions of the Civil Code of Ukraine, the medical institution remains fully responsible to the customer for breach of contract.

\footnotetext{
${ }^{8}$ Цивільний кодекс України від 16. 01. 2003p. № 435-IV. Відомості Верховної Ради України. 2003. № № 40-44. Ст. 356 .

${ }^{9}$ Основи законодавства України про охорону здоров'я 19 листопада 1992 року. Відомості Верховної Ради України. 1993. № 4. Ст. 19.

${ }^{10}$ Герц А. А. Класифікація договорів про надання медичних послуг Науковий вісник Ужгородського національного університету. Серія : Право. 2015. Вип. 32(2). С. 16-20. URL : http://nbuv.gov.ua/UJRN/nvuzhpr_2015_32\%282\%29_5 (дата звернення 12.01.2020)
} 
It should be noted that the issue of the responsibility of medical professionals is also extremely important, because for the current stage of development of the health care system, there is a contradiction between the need to respect the individual rights of the patient in the provision of medical care and the real conditions for the exercise of these rights. Because, according to experts, medical practice is an activity characterized by frequent unpredictable results and high risk of harm to the patient.

The current legislation of Ukraine does not establish the peculiarities of civil liability of medical professionals for the harm to life and health caused in the course of their professional activity. The legal regulation of such relations is carried out in accordance with the general provisions of civil law in the tort area.

It should be noted that civil liability in the field of medical activity is a type of legal liability that arises as a result of violations in the field of property or personal non-property benefits of citizens in the field of health care and which consists mainly in the need for compensation for harm.

Personal non-pecuniary benefits of citizens, which are directly related to medical activity, are primarily life and health. For this reason, it can be argued that civil liability is a peculiar means of ensuring the protection of personal non-property rights (life and health) of patients in the provision of medical care ${ }^{11}$. According to the existing theoretical provisions of civil law, the main function of obligations for compensation of damages (torts) is a compensatory-restorative function, the realization of which should provide the injured person with the restoration of his property and personal nonpecuniary rights ${ }^{12}$.

Most health care professionals carry out their professional activities while working with healthcare institutions. In accordance with Part 1 of Article 1172 of the Civil Code of Ukraine, a legal or natural person shall indemnify the damage caused by their employee in the course of performing their work (official) duties.

However, it should be noted that the legal or natural person - the employer has the right of recourse to the direct harm. As for healthcare providers providing private medical practice, they are solely responsible for the general principles of tort.

${ }^{11}$ Відповідальність медичних працівників : Лист Міністерства юстиції України від 20.06.2011. URL: http://zakon2.rada.gov.ua/laws/show/n0040323-11 (дата звернення 12.01.2020).

12 Цивільне право України. Академічний курс. Підруч.: У двох томах. Т.2. Особлива частина. / За заг. ред Шевченко Я.М. К.: Концерн «Видавничий Дім “Ін Юре”», 2003. $408 \mathrm{c}$. 
Damage caused by a healthcare professional is referred to civil law by a group of special torts, as liability for damage caused by injury, other damage to health or death. Such compensation has a number of features, namely: 1) damage to the life and health of the highest value person; 2) the impossibility of compensation for such damage in kind and its evaluation in monetary terms.

In this case, the harm is inflicted on the patient in the provision of medical services, characterized as property (real costs: loss of earnings, costs for treatment, prosthetics, nutrition, special care, etc.) and moral (physical pain and suffering) $)^{13}$.

Therefore, it can be concluded that the responsibility for the harm to the patient is caused in the course of carrying out medical activity, the current legislation places personally on the medical professional.

This should take into account the number of people dissatisfied with the quality of medical services provided, whose claims, as a rule, are transformed into civil lawsuits - all this necessitates the need to improve the existing mechanism of compensation for the harm caused by introducing professional liability insurance for medical professionals.

Today, there are various forms in the world that allow healthcare professionals to protect themselves from the negative effects of medical errors.

First, the cost of the medical service can be used to provide a share that will form a guarantee fund in the event of a claim. Secondly, mutual insurance funds may be created through professional associations of health care providers. Thirdly, it is professional liability insurance by insurance organizations.

This form of protection of the interests of health care professionals and patients is fundamental in the world. The study of the existing international experience of professional liability insurance related to professional medical activity is developing in two directions: tort liability insurance and the system of liability insurance against damage that occurred without the fault of the insured ${ }^{14}$.

The Law institute of insurance is aimed at protecting the property and personal non-property interests of a person, and its main function is compensatory, aimed at their restoration.

${ }^{13}$ Антонов В.С. Особливості відшкодування шкоди, заподіяної пацієнтові невдалим медичним втручанням Управління закладом охорони здоров'я. №7. 2007 URL: http://www.medlawcenter. com.ua/ru/publications/76.html.

${ }^{14}$ Антонов В.С. Особливості відшкодування шкоди, заподіяної пацієнтові невдалим медичним втручанням Управління закладом охорони здоров'я. № 7, 2007 URL: http://www.medlawcenter. com.ua/ru/publications/76.html. 
Therefore, in our opinion, the introduction of a statutory mechanism for the insurance of professional liability of medical professionals is now a pressing issue. In addition, the effectiveness of this mechanism will be greatly enhanced if it is implemented in the context of reforms in the health sector, in particular the introduction of a compulsory health insurance system and the improvement of the voluntary health insurance system.

\section{Introduction of the compulsory health insurance system as one way to exercise the non-property right to health care}

Finding new sources of financing for the industry, improving the efficiency of use of funds allocated for health care is possible in the case of introduction of compulsory health insurance in Ukraine as a necessary condition for reforming the health care industry. The problem of introduction of compulsory health insurance, which would be included in the social security system of the state, is not actively investigated today.

It should be noted that the effectiveness of health insurance depends primarily on how perfect is the concept of introduction and development of insurance medicine in the country.

Today, there are several fundamentally different health systems: mainly state-owned, such as in the UK; mainly insurance, which combines compulsory and voluntary insurance and is typical of most European countries (Germany, France, Austria, Switzerland, etc.) and predominantly a paid (private) system in the US.

Studying the experience of other countries that they have acquired in the process of introduction of the medical insurance system can certainly be useful in order to avoid their own mistakes in the law making process, but it is necessary to investigate the dynamics of the development of one or another health care system and use it best, adapting to the existing economic ones and social conditions in our country.

The compulsory insurance model appears to be the most effective and suitable for implementation in Ukraine, which is characterized by the following features:

1) compulsory insurance through non-profit insurance organizations;

2) solidarity building (insurance premiums depend on income, not age and health);

3) legislative regulation of necessary types of medical services;

4) protecting the interests of persons with disabilities, pensioners, the unemployed, by providing them with medical care at budgetary cost;

5) preferential insurance conditions for the underprivileged population and minors; 
6) provision of compulsory voluntary insurance to cover the cost of additional costs (for example, the provision of medical services not listed in the required list), etc.

It is impossible to carry out any reform in the country without creating a proper legal basis that would determine the programmatic set of measures to reform the health care system, the concept and legal status of compulsory health insurance, the possibility of combining it with voluntary insurance and the system of budget financing.

At present, the norms of current legislation, in particular Art. 18 Fundamentals of health care legislation stipulate that health care financing is provided at the expense of the State Budget of Ukraine, the budget of the Autonomous Republic of Crimea, local and regional self-government budgets, health insurance funds, charitable foundations and any other sources not prohibited by law ${ }^{15}$, and in Art. 4 Fundamentals of Ukrainian legislation on compulsory state social insurance ${ }^{16}$ health insurance is available. In addition, the Decree of the Cabinet of Ministers of Ukraine No. 1013-p of November 30, 2016 approved the main conceptual directions of reforming the health care system and provided for the need to regulate at the legislative level the issue of the introduction of state solidarity health insurance ${ }^{17}$.

At the moment, several draft laws on compulsory health insurance are under consideration in the Verkhovna Rada committees, in particular the draft Law of Ukraine "On compulsory state social insurance" No. 1040 of 27.11.2007, the draft Law of Ukraine "On compulsory health insurance State Social Insurance" No. 1040-1 of December 18, 2007, Draft Law "On Amendments to Some Laws of Ukraine (on Introduction of Compulsory State Social Health Insurance)" No. 1040-2 of January 25, 2008.

Among the provisions of these bills is defined the concept of compulsory health insurance as an integral part of the system of compulsory state social insurance and a form of protection of the population in the field of health care; formulated principles of health insurance, in particular the principle of solidarity and subsidization, the principle of providing state guarantees for

15 Основи законодавства України про охорону здоров'я 19 листопада 1992 року Відомості Верховної Ради України. 1993. № 4. Ст. 19.

16 Основи законодавства України про загальнообов'язкове державне соціальне страхування 14 січня 1998 року Відомості Верховної Ради України. 1998. № 23. Ст. 121.

${ }^{17}$ Концепція реформи фінансування системи охорони здоров'я : Розпорядження Кабінету Міністрів України від 30 листопада 2016 p. № 1013-p URL: https://zakon.rada.gov.ua/laws/ show/1013-2016$\% \mathrm{D} 1 \% 80$ ?find=1\&text=\%D1\%81\%D1\%82\%D1\%80\%D0\%B0\%D1\%85\% D1\%83\%D0\%B2 (дата звернення 12.01.2020) 
the realization by the insured persons of their rights to free medical care, the principle of purposeful use of health insurance funds, the principle of ensuring that the necessary medical assistance is sufficient in the event of an insured event, the principle of compulsory financing by the Health Insurance Fund of the costs associated with the provision of health care, the principle of ensuring the possibility of voluntary participation in the compulsory insurance scheme for persons for whom it is not provided.

The draft laws also outline the number of persons subject to insurance, namely working citizens of Ukraine, stateless persons and foreigners, unemployed, students, minors, etc. It is envisaged that the payers of insurance premiums, ie the insurers are employers, the state, the relevant funds of compulsory state social insurance (for pensioners, the disabled, the unemployed) and self-employed persons (for example, lawyers, notaries, private entrepreneurs).

A separate list of bills defines the list of medical services; the rights and obligations of the insured person, the insured person and the healthcare provider; the procedure for determining the amount, calculation and payment of insurance premiums; a health insurance management system with a leading position in the Health Insurance Fund (or Compulsory Social Health Insurance Fund), which is a non-profit self-government organization, etc.

It is determined that insured persons are issued a certificate of compulsory health insurance, which confirms their right to receive medical care and which is obligatory presented when seeking medical help.

Such certificates, in particular, may have the appearance of an electronic card, which will greatly facilitate the transfer and receipt of information. Compulsory health insurance is provided on the basis of a contract concluded between the Health Insurance Fund and the health care provider. This status may be granted to a medical institution that has received appropriate accreditation and licensing.

According to the analysis, certain bills, although different in content, but regulate the same range of public relations and considered alternative, and therefore developers are invited to take one of them as a basis or on the basis of all submitted projects to develop one - a generalization. The next step in the drafting was bill No. 4279 of March 30, 2009, "On Health Care Financing and Health Insurance", which was withdrawn on May 22, 2009. So, it can be noted that at present, there is no current regulatory framework for the introduction of insurance medicine in Ukraine.

However, among the many positive aspects of these bills, there are some disadvantages, which include the absence of a clearly defined concept of compulsory health insurance, the lack of determination of the possibility and conditions of combination of compulsory and voluntary insurance, certain 
aspects of expert evaluation of the quality of medical services. In our opinion, the adoption of a single law that defines the general principles of compulsory health insurance in Ukraine will not solve the problem of financing the health care industry and will not ensure the proper exercise of the right of the individual to health care, requires complex, purposeful and coordinated law-making work. An urgent need is the adoption of a number of regulations that would determine the directions of structural reform of the health care industry, reveal the sources of its financing, methods of organization and remuneration, formulate requirements for the quality of health services and more.

\section{Improvement of the voluntary health insurance system}

\section{as an additional means of securing non-material right to health care}

The system of compulsory state insurance, which is successfully operating in many developed countries, is currently undergoing legislative work in Ukraine and is unformed. Insufficient funding for national medicine requires finding ways to provide alternative and guarantee the right of a person to provide quality medical services. The solution to this problem may be the development of voluntary health insurance.

Voluntary health insurance, as well as compulsory health insurance, aims to secure the right to provide medical assistance on the basis of insurance funding, but the achievement of this goal is achieved by various means. Yes, voluntary insurance is commercially available, relates to personal insurance, and is an effective complement to budget financing or the compulsory health insurance system. Voluntary insurance operates on the basis of equivalence, that is, the volume of health care delivery depends on insurance premiums and is able to meet the individual needs of individuals.

The benefits of voluntary health insurance include: the ability to minimize the cost of medical care; the possibility of receiving more qualified medical care in more comfortable conditions; availability of independent expert control over the terms, quality and volumes of medical services provided by the insurer's representatives.

In the European Community, voluntary health insurance is divided into three types:

1. Insurance, which is a substitute for the state insurance system provided by the current legislation and provides insurance for persons not covered by this system.

2. Insurance, which enables additional coverage of those medical services that are not covered by the state insurance system.

3. Insurance that covers the cost of expedited access or a wider range of health care services. 
As the analysis shows, the regulatory framework for voluntary health insurance is in the making. Existing legislation does not cover the whole range of public relations that arise in the course of voluntary health insurance. The place and compulsory health insurance in the system of insurance protection of citizens and the list of medical services provided within the guaranteed scope have not been determined; the composition of the subjects of voluntary health insurance with the fixing of their rights and obligations is not regulated. Such imperfection of the current legal framework governing relations in the field of health care provision and insurance puts the subjects of voluntary health insurance in unequal conditions.

Some provisions on voluntary health insurance are contained in the provisions of the Law of Ukraine "On Insurance" of 7 March $1996{ }^{18}$. Article 6, which stipulates that voluntary insurance is insurance that is provided on the basis of a contract between the insured and the insurer, also defines health insurance (continuous health insurance) among other types of insurance.

The aforementioned law stipulates that the general conditions and procedure for the implementation of voluntary insurance shall be determined by the insurance rules established by the insurer independently, and the specific insurance conditions shall be determined when concluding the insurance contract.

From an economic point of view, health insurance is a mechanism to compensate individuals for the costs associated with the occurrence of an insured event (illness or accident) and treatment of the insured person for medical assistance. The subject of voluntary health insurance is the cost of necessary medical care for the insured person in the event of his or her illness or accident. As practice shows, insurance companies evaluate the level of modern medicine and analyze the needs of consumers of insurance services, develop the Insurance Rules and draw up specific programs of voluntary health insurance. The medical insurance program is an integral annex to the insurance contract, which defines a specific variant of medical care. The programs are different - depending on the list of medical services and medical institutions, the contingent of insured persons, and also differ in the cost, which is influenced by all the above factors ${ }^{19}$. The medical insurance program may be modified during the term of the insurance

18 Про страхування: Закон України від 07.03.1996 p. № 85/96-ВР Відомості Верховної Ради Украӥни. 1996. № 18. Ст. 78.

${ }_{19}$ Внукова Н.М., Кузьминчук Н.В. Соціальне страхування: Кредитно-модульний курс. Навч посіб. К.: Центр учбової літератури, 2009. 412 с. 
contract with the consent of the insurer, provided the insurer makes additional insurance payments.

Voluntary health insurance programs vary depending on the list of health care services (for example, inpatient care or a doctor's call home); circles of insured persons (services for children or adults); the list of medical institutions offered by the insurance organization for the implementation of the voluntary health insurance program; from the cost of services provided, etc.

The specific functions of voluntary health insurance include: compensation, preventive and incentive, which reflects the need for treatment facilities to have the greatest effect on adequate costs and incentives for the insured person not to create health risks.

Unlike compulsory health insurance, which is based on the principle of solidarity, voluntary health insurance is based on the principle of insurance equivalence, and therefore the insured person receives those types of health services and in such amounts for which the premiums were paid. The object of voluntary health insurance is the property interests of the insurer and the insured person related to the cost of obtaining medical assistance in the event of an insured event, which refers to the insured person's treatment of the medical care provided under the contract (insurance policy).

The subjects of voluntary health insurance are insurance companies, insurers, insured persons, health care establishments. The relationship between these persons is based on the concluded contracts: the contract between the insurer and the insured (the insured person) and the contract between the insurer and the health care institution.

The insurance contract is defined by the provisions of the Civil Code of Ukraine and the Law of Ukraine "On Insurance" as a written agreement between the insurer and the insurer, under which the insurer undertakes to pay the insurer or other person specified in the insurance contract in the event of an insured event the insurer in favor of which the insurance contract is concluded (to provide assistance, to perform the service, etc.), and the insurer undertakes to pay insurance payments within a specified period and to fulfill other the language of the contract.

Compulsory elements of the insurance contract are: the name of the document; the name and other details of the insurer; surname, first name, patronymic or name of the insured and the insured person, their address and date of birth; the surname, first name, patronymic, date of birth or name of the beneficiary and his address; the subject of the insurance contract; the amount of the insurance amount; list of insured events; the amount of insurance premiums (payments, premiums) and terms of their payment; insurance rate; term of the contract; the procedure for modification and termination of the contract; conditions of payment of insurance payment; reasons for refusal of insurance payment; the rights and obligations of the 
parties and the liability for non-performance or improper performance of the contract; other terms with the consent of the parties.

Essential components of a voluntary health insurance contract should also be: medical insurance programs selected by insurers; a list of health care facilities to which the insured person should seek medical assistance; individual insurance rates for each insured person, determined either by the results before the insurance medical examination or otherwise under the terms of the insurance contract; calculation of insurance payments for each insured person, based on the composition of medical insurance programs ${ }^{20}$.

The voluntary health insurance contract is concluded on the basis of an oral or written statement of the policyholder, and the fact of conclusion of the contract is certified by the insurance policy. As foreign experience shows, insurance companies can offer insurers universal and specialized health insurance policies. The universal policy, as an insurance policy, envisages those cases in which medical assistance in which does not require special treatment or consultation of doctors of narrow specialties. Cases requiring a district doctor's call home if ill, fever, acute respiratory illness may be considered as insurance.

The list of insured events may be unified and may be determined by agreement between the insurer and the insurer with the possible involvement of the clinical service base. Organizing a universal insurance policy may involve seeking the services of a family physician.

Specialized insurance policies make it possible to use the medical services of highly specialized medical specialists or to take only certain health conditions (pregnancy, childbirth, HIV / AIDS infection, etc.). Specialized health policies are mostly covered by people who are already ill or are prone to certain diseases. If universal insurance policies are targeted at individuals, specialized ones are often provided under collective insurance contracts, in cases where businesses and organizations insure their employees against the greatest possible professional risks ${ }^{21}$.

The content of the health insurance contract is determined by the type and methods of necessary medical care and is determined by each insurer independently in accordance with the license obtained. Due to this, there are basic types of health insurance and additional (options). The main ones include the costs of outpatient and inpatient treatment, which means that the cost of basic treatment is guaranteed. Additional types cover the costs

20 Яворська Т.В. Страхові послуги: навчальний посібник. Львівський ун-т ім. І.Франка. Економічний факультет. К.: Знання, 2008. 350 с.

${ }^{21}$ Безугла В.О., Загірняк Д.М., Шаповал Л.П. Соціальне страхування. навч. посіб. К.: Центр учбової літератури, 2011. 208 с. 
associated with treatment and the cost of specialized medical care (prosthetics, dentistry, etc.).

Depending on the volume, there are: full insurance of medical expenses, which guarantees reimbursement of expenses for both outpatient and inpatient treatment; partial - guarantees the reimbursement of the costs of either outpatient or inpatient treatment or the provision of specialized treatment at the option of the insured person. There is also the possibility of insurance for only one risk.

Insurance indemnity under voluntary health insurance contracts may be determined by: a firm sum within which the insured person's annual medical expenses are paid; a list of insured events for which full reimbursement of the cost of treatment is guaranteed; the list of costs for the provision of medical services with the limited liability of the insurer for each type.

The voluntary health insurance contract usually includes a list of conditions under which the insurer is entitled to not fulfill its obligation to pay the sum insured. For example, the insurer may reimburse the medical institution for the cost of services provided to the insured in the event of his or her treatment in connection with an injury resulting from alcohol, narcotic or toxic intoxication as a result of a deliberate crime, attempted suicide, or intentional bodily harm. damage, etc.

General provisions of the Civil Code of Ukraine for service contracts apply to the contract for the provision of medical services.

A type of health insurance contract is an insurance contract for persons traveling abroad in case of illness, injuries - the so-called assistance contract. The main purpose of such contracts is to respond quickly to an emergency. The contract generally provides for the insurer's obligations to transport the insured person to a nearby or specialized hospital and to provide emergency medical care; transportation to the country of residence with medical support; emergency dental care and more ${ }^{22}$.

At the same time, such contracts do not provide for the obligation of the insurer to reimburse the cost of targeted medical services abroad; reimbursement of the costs of treating diseases known at the time of contract and chronic diseases; reimbursement of expenses for treatment of diseases which are not urgent (eg dental prosthetics), etc.

${ }^{22}$ Безугла В.О., Загірняк Д.М., Шаповал Л.П. Соціальне страхування. навч. посіб. К.: Центр учбової літератури, 2011. 208 с. 
Assistance companies are engaged in direct customer service abroad these are organizations that carry out 24/7 coordination of assistance to insured persons in the event of an insured event.

Therefore, given that at present, due to lack of financial capacity, the Ukrainian state cannot fully ensure the realization of the citizens' constitutional right to health care and medical care, and the compulsory health insurance system is unregulated and does not provide a valid regulatory framework. The social importance of voluntary health insurance, which can be an additional source of funding, is growing.

\section{CONCLUSIONS}

Ensuring the exercise of the individual's non-proprietary right to health care and health care today largely depends on the effectiveness of health care reform, including changing the delivery of care at different levels and funding arrangements. Finding new sources of financing for the industry, improving the efficiency of use of the funds allocated for health care is possible in our opinion, if the introduction of compulsory health insurance in Ukraine, as a necessary condition for reforming the health care industry. Unfortunately, today the system of compulsory state insurance, which is successfully operating in many developed countries, in Ukraine is undergoing a stage of legislative work and is unformed. In addition, the lack of funding for the healthcare industry requires finding alternative ways of securing and guaranteeing a person's non-proprietary right to provide quality medical services. The solution to this problem may be the development of a voluntary health insurance system.

\section{SUMMARY}

The article analyzes certain types of personal non-property rights of an individual as defined by civil law, namely the rights to health care and medical care. These rights belong to the group of personal nonproprietary rights that ensure the natural existence of man, are inalienable, and are subject to protection, because human health is an overriding social value of the modern state and the basis for future generations. It is noted that the specificity of securing and exercising certain rights lies in the current and legally enforced health care system, which is based on budget financing, which is not without significant deficiencies today. In Ukraine, an active reform of the medical sector is underway. One of the directions of such reform is to change the principles of financing the provision of medical services and the basis for establishing contractual relations between patients and healthcare professionals. The contract on public health services regulates and 
determines the terms and scope of the provision of medical services and medicines to insured persons. The article also analyzes the problems of liability of medical workers for failure to provide or improper provision of medical services, and notes that there is a need to improve the existing mechanism of compensation for harm caused by introducing professional liability insurance for medical professionals.

The article points out that securing non-property rights to health and medical care requires finding new sources of funding for the industry and increasing the efficiency of spending on health care. In our opinion, this is possible in the case of the introduction of compulsory health insurance in Ukraine as a necessary condition for reforming the healthcare sector. The effectiveness of health insurance depends first and foremost on how perfect the concept of introducing and developing insurance medicine in the country is. Against this background, the article analyzes current health care systems in the world and proposes the introduction of an optimal system, characterized by specific features.

Also, the article noted that the lack of funding for national medicine requires finding ways to provide alternatives and guarantee the right of a person to provide quality medical services. The solution of this problem may be the development of voluntary health insurance.

As a result, it should be noted that the adoption of separate laws defining the general principles of compulsory health insurance in Ukraine will not solve the problem of financing the health care industry and will not ensure the proper exercise of the individual's right to health care, since it requires a comprehensive, purposeful and coordinated lawmaking work.

\section{REFERENCES}

1. Цивільний кодекс України від 16. 01. 2003p. № 435-IV. Відомості Верховної Ради Украӥни. 2003. № № 40-44. Ст. 356 .

2. Коротка Н.О. Особисті немайнові права фізичних осіб в сфері охорони здоров'я : автореф. дис. ... канд. юрид. наук : 12.00.03. Київ, 2015. $20 \mathrm{c}$.

3. Стефанчук Р. О. Особисті немайнові права фізичних осіб у цивільному праві :автореф. дис. ... докт. юрид. наук: 12.00.03. Київ, 2007. $40 \mathrm{c}$.

4. Конституція України : офіц. текст. Київ : КМ, 2013. 96 с.

5. Рішення Конституційного Суду України у справі за конституційним поданням 53 народних депутатів України щодо офіційного тлумачення положення частини третьої статті 49 Конституції України “у державних i комунальних закладах охорони здоров'я медична допомога надається безоплатно" (справа про безоплатну медичну 
допомогу) від 29.05.2002. URL: https://zakon.rada.gov.ua/laws/show/ v010p710-02 (дата звернення 11.01.2020).

6. Про державні фінансові гарантії медичного обслуговування населення: Закон України від 19.10.2017 р. № 2168-VIII. Вiдомості Верховної Ради. 2018. № 5. Ст. 31.

7. Про державні фінансові гарантії медичного обслуговування населення: Закон України від 19.10.2017 р. № 2168-VIII. Вiдомості Верховної Ради. 2018. № 5. Ст. 31.

8. Основи законодавства України про охорону здоров'я 19 листопада 1992 року. Відомості Верховної Ради Украӥни. 1993. № 4. Ст. 19.

9. Герц А. А. Класифікація договорів про надання медичних послуг Науковий вісник Ужггородського начіонального університету. Серія : Право. 2015. Вип. 32(2). С. 16-20. URL: http://nbuv.gov.ua/UJRN/ nvuzhpr_2015_32\%282\%29_5 (дата звернення 12.01.2020).

10. Відповідальність медичних працівників : Лист Міністерства юстиції України від 20.06.2011. URL: http://zakon2.rada.gov.ua/ laws/show/n0040323-11 (дата звернення 12.01.2020).

11. Цивільне право України. Академічний курс. Підруч.: У двох томах. Т. 2. Особлива частина. / За заг. ред Шевченко Я.М. К.: Концерн “Видавничий Дім "Ін Юре”, 2003. 408 с.

12. Антонов В.С. Особливості відшкодування шкоди, заподіяної пацієнтові невдалим медичним втручанням Управління закладом охорони здоров'я. № 7. 2007 URL: http://www.medlawcenter.com.ua/ru/ publications/76.html (дата звернення 12.01.2020).

13. Основи законодавства України про охорону здоров'я 19 листопада 1992 року Відомості Верховної Ради Украӥни. 1993. № 4. Ст. 19.

14. Основи законодавства України про загальнообов'язкове державне соціальне страхування 14 січня 1998 року Biдомості Верховної Ради Украӥни. 1998. № 23. Ст. 121.

15. Концепція реформи фінансування системи охорони здоров'я : Розпорядження Кабінету Міністрів України від 30 листопада 2016 р. № 1013-p URL: https://zakon.rada.gov.ua/laws/show/1013-2016-\%D1\% 80 ?find $=1 \&$ text $=\%$ D $1 \% 81 \%$ D1\%82\%D1\%80\%D0\%B0\%D1\%85\%D1\%83 $\% \mathrm{D} 0 \% \mathrm{~B} 2$ (дата звернення 12.01.2020)

16. Про страхування: Закон України від 07.03.1996 р. № 85/96-ВР Відомості Верховної Ради України. 1996. № 18. Ст. 78.

17. Внукова Н.М., Кузьминчук Н.В. Соціальне страхування: Кредитно-модульний курс. Навч посіб. К.: Центр учбової літератури, 2009. 412 c. 
18. Яворська Т.В. Страхові послуги: навчальний посібник. Львівський ун-т ім. І. Франка. Економічний факультет. К.: Знання, 2008. $350 \mathrm{c}$.

19. Безугла В.О., Загірняк Д.М., Шаповал Л.П. Соціальне страхування. навч. посіб. К.: Центр учбової літератури, 2011. 208 с.

\section{Information about the author:} Manzhosova O. V.,

Head of the Department of Civil Law Disciplines, Chernivtsi Law Institute, National University "Odessa Law Academy" 7, Skovorode str., Chernivtsy, Ukraine Chernivtsy, Skovorode str., 7 ORCID ID https://orcid.org/0000-0002-8873-4783 